\title{
Arterial reconstructions of kidney allograft
}

\author{
S. R. Vildanov ${ }^{1}$, A. O. Nykonenko ${ }^{2}$, I. V. Rusanov ${ }^{1}$, 0. S. Nykonenko ${ }^{1,2}$ \\ ${ }^{1}$ State establishement: "Zaporizhzhia Medical Academy of Postgraduate Education Ministry of Health Protection in Ukraine", \\ 2Zaporizhzhia State Medical University, Ukraine
}

The adequacy of blood supply in the allograft is one of the main factors of kidney transplant vitality and function and the effectiveness of transplantation itself.

The aim of the study was to investigate the effectiveness and variants of arterial reconstructions of kidney allograft.

Material and Methods. The results of kidney transplantation were analyzed among 66 patients. During the period from 2012 to 2016 , all of them were done kidney transplantation in the department of transplantology. There were 37 (56.1\%) men, 29 women (43.9\%), the average age at the time of surgery was $33.2 \pm 12.0$ years. According to the aim of the study all the patients were divided into two groups: the first group included $12(18.2 \%)$ recipients, who received an arterial reconstruction. The age of the patients was $30.8 \pm 6.5$ years, there were $6(50 \%)$ men, other - women. Another group involved $54(81.8 \%)$ patients without arterial reconstruction. The average age of recipients was $33.7 \pm 12.9$ years, there were $31(57.4 \%)$ men, 23 women (42.6\%). We analyzed duplex examination of kidney allograft on the $7.6 \pm 1.9$ day after kidney transplantation.

Results. According to the analysis of duplex examination the features of blood disorder in kidney allografts were not determined. The differences between groups were non-significant $(p>0.05)$. There were not identified any stenosis, thrombosis or bleeding in any cases of arterial reconstructions of kidney allograft; function of kidney allograft has preserved for the period of $2.2 \pm 1.4$ years.

Conclusions. Adequate arterial reconstruction of kidney allograft is effective and safe method of kidney preparation for transplantation.
Key words:

kidney

transplantation,

allografts,

renal artery.

Zaporozhye medical journal 2017; 19 (1),

41-45

DOI:

10.14739/2310-1210 2017.1.91633

E-mail:

vildanov009@gmail.com: nikonandra@gmail.com; 00106@mail.ru

Киючові слова: трансплантація нирки, аммотрансплантати, ниркова артерія.

Одним із принципових фракторів життєздатності та функції пересадженої нирки, а отже й ефективності трансплантації, є адекватність кровотоку в аллотрансплантаті.

Мета роботи - вивчити ефективність і варіанти артеріальних реконструкцій ниркового аллотрансплантату.

Матеріали та методи. Проаналізовані результати трансплантації нирки 66 хворим. 32012 по 2016 р. їм виконана пересадка нирки у відділенні трансплантації. Чоловіків було 37 (56,1\%), жінок-29 (43,9\%), середній вік пацієнтів - 33,2ะ12,0 року. Згідно з метою роботи пацієнтів поділили на групи: першу становили 12 (18,2\%) реципієнтів, яким виконане хірургічне втручання на артеріях трансплантату. Середній вік пацієнтів - 30,8 26,5 року, чоловіків було 6 (50 \%), інші - жінки; друга група - 54 (81,8 \%) пацієнти, в яких не було необхідності в артеріальних реконструкціях аллонирки. Середній вік реципієнтів - 33,7士12,9 року, чоловіків було 31 (57,4\%), жінок-23 (42,6\%). Аналізували дуплексне сканування ниркового аллотрансплантату в середньому

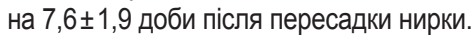

Результати. Під час дуплексного ультразвукового сканування ознак порушення кровотоку в ниркових аллотрансплантатах не виявили. Відмінності між групами статистично невірогідні ( $p>0,05)$. У жодному випадку не зареєстровано стенозів, тромбозів або кровотеч; за період спостереження 2,2ะ1,4 року функція аллонирок збережена.

Висновки. Адекватна артеріальна реконструкція ниркового аллотрансплантату - ефективний і безпечний спосіб підготовки нирки до пересадки.

\section{Артериальные реконструкции почечного аммотрансплантата}

\section{С. Р. Вильданов, А. А. Никоненко, И. В. Русанов, А. С. Никоненко}

Одним из принципиальных факторов жизнеспособности и функции пересаженной почки, а следовательно, и эффективности трансплантации является адекватность кровотока в аллотрансплантате.

Цель работы - изучить эффективность и варианты артериальных реконструкций почечного аллотрансплантата.

Материалы и методы. Проанализированы результаты трансплантации почки 66 больным. За период с 2012 по 2016 г. им была выполнена пересадка почки в отделении трансплантации. Мужчин было 37 (56,1\%), женщин - 29 (43,9\%), средний возраст пациентов - 33,2 12,0 года. Согласно цели работы пациенты были разделены на группы: первую составили 12 $(18,2 \%)$ реципиентов, которым было выполнено хирургическое вмешательство на артериях трансплантата. Средний возраст пациентов - 30,8 6,5 года, мужчин было 6 (50\%), другие - женщины. Вторая группа - 54 (81,8\%) пациента, у которых не было необходимости в артериальных реконструкциях аллопочки. Средний возраст реципиентов $-33,7 \pm 12,9$ года, мужчин - 31 (57,4 \%), женщин - 23 (42,6\%). Мы анализировали дуплексное сканирование почечного аллотрансплантата в среднем на $7,6 \pm 1,9$ суток после пересадки почки.
Ключевые слова: трансплантация почки, аммотрансплантаты, почечная артерия.

Запорожский медицинский журнал. - 2017. T. 19, № 1(100). C. 41-45 
Результаты. При дуплексном ультразвуковом сканировании признаков нарушения кровотока в почечных аллотрансплантатах обнаружено не было. Различия между группами статистически недостоверны $(p>0,05)$. Ни в одном случае не было зарегистрировано стенозов, тромбозов или кровотечений; за период наблюдения $2,2 \pm 1,4$ года функция аллопочек сохранена.

Выводы. Адекватная артериальная реконструкция почечного аллотрансплантата является эффрективным и безопасным способом подготовки почки к пересадке.

Nowadays, it can be noticed the increase of discrepancy between the necessity in donor material and its availability. As a result, it is necessary to develop a complex approach in view of the transplantations number increase. One of the conditions is the acceptability of organs with anatomical peculiarities [1].

The adequacy of blood supply in the allograft is one of the main factors of kidney transplant vitality and function and the effectiveness of transplantation itself [2]. Preparation kidney for transplantation has the primary importance and it can not be underestimated. As a result, different variants of vascular reconstructions have been studied and improved.

According to the literature data in $10-15 \%$ cases the requirement in different arterial reconstructions of allograft vessels has appeared [3].

Taking into account the long-term results of transplantation of multiarterial kidney allografts it is noticed the increasing of ischemia time $[4,5]$. This fact influences very negatively the functional suitability of transplant [6-8]. It is noticed the increasing risk of complications development $[5,9]$. Other authors deny this point of view and demonstrate the safe of the multiarterial kidney allografts using in their studies [10,11]. The forecast kidney allograft survival depends significantly on the surgical technology quality $[1,3,12-15]$.

The aim of the study was to investigate the effectiveness and variants of arterial reconstructions of kidney allograft.

\section{Material and Methods}

The results of kidney transplantation were analyzed among 66 patients. During the period from 2012 to 2016, all of them were done kidney transplantation in the department of transplantology of State establishment "Zaporizhzhia Medical Academy of Post-Graduate Education Ministry of Health of Ukraine" on the base of interregional centre of transplantology. There were $37(56.1 \%)$ men, 29 women $(43.9 \%)$, the average age of patients was $33.2 \pm 12.0$ years All the patients in the early postoperative period were done the standard examinations for clinical records, ultrasonic examination with scanning of kidney allograft (the figures of ultrasonic examination are presented on average the $7.6 \pm 1.9$ day after kidney transplantation).

As for multiple renal arteries of donor kidney allograft from live related donor the ostium of the upper pole kidney allograft artery was dissected on the caudal surface. The ostium of the kidney allograft artery lower pole was dissected on the cranial surface for about $1.0 \mathrm{~cm}$. Common neo-ostium was formed with two-lane uninterrupted suture (polypropylene suture 6-0) like "side-to-side". As for multiple renal arteries, their length and distance between them were taken into account. As for hemodynamic little additional upper pole renal artery (diameter to $2 \mathrm{~mm}$ ) the last one was bound.

Short renal artery was elongated by the way of anastomosis with synthetic vascular prosthesis GORE-TEX $\varnothing 6$ $\mathrm{mm}$ like "end-to-end" with the help of polytetrafluoroethylene suture 6-0. In case of revealing the atherosclerosis plaque of renal artery endarterectomy was done.

In all cases renal artery was anastomosed with external iliac artery like "end-to-side".

According to the aim of the study all the patients were divided into two groups.

The first group included 12 (18.2\%) recipients, everyone of them was done an arterial reconstruction of kidney allograft. The average age of patients was $30.8 \pm 6.5$ years, there were $6(50 \%)$ men and 6 women (50\%).

The second group involved $54(81.8 \%)$ patients. They were not required for arterial reconstructions of the kidney allograft. The average age of recipients was $33.7 \pm 12.9$ years, there were 31 (57.4\%) men, 23 women (42.6\%).

As for sexual and age-old features, nosology of terminal stage of chronic renal failure these groups are representative $(p>0.05)$.

For description of frequent data the percentages were used, the differences among groups were estimated with the help of $x^{2}$-test and Fisher's exact test. Kolmogorov-Smirnov test was used to check up the form of data division. Continuous normally divided data was denoted by the average value and standard deviation. Unmatched t-criterion was used for comparison of average data of independent samples. As for continuous data with division, distinctive from normal one, median, lower and upper quartiles were been in usage. In order to compare the groups in pairs U-test by Mann-Whitney was used (as for independent samples). The availability of connection between parametric data was evaluated with the help of correlation coefficient Pearson's (r). Nonparametric data was estimated with the help of Spirman's coefficient. The power of connection was interpreted following the notion of correlation's coefficient in such way: from \pm 0.7 to \pm 1 - it is strong correlation, from \pm 0.3 to \pm 0.699 - it is middle correlation, from \pm 0 to \pm 0.299 - it is weak correlation.

All types of analysis were performed with the usage of programmes of statistical analysis Microsoft Office Excel 2007 and "Statistica 6.0" for Windows (StatSoft Inc., США) v.6.1 license № AXXR712D833214FAN5. Differences between groups, prognostic value of criterion, correlational dependence were reliable at $p<0.05$. In all cases values $p$ were bidirectional.

\section{Results and Discussion}

The structure of arterial reconstructions of kidney allograft was the following: in 8 cases (57\%) general arterial ostium was formed, in 4 cases $(29 \%)$ - additional upper pole renal artery was bound. In 1 case (7\%) - previously formed common neo-ostium of renal artery was continued with the help of synthetic vascular prosthesis, in 1 case $(7 \%)$ - the endarterectomy was done (with simultaneous formation of common ostium of renal artery).

Cold ischemia time in the first group was 2.25 (2.043.18), in another it was 2.0 (1.5-2.27) hours. According to the results of U-test as for Mann-Whitney's method statistically 
true differences $(p=0.020)$ are determined. Between surgery on the kidney allograft's arteries and cold ischemia time the correlation is absent $(R=0.356, p=0.018)$.

Secondary warm ischemia in the first group was 39.0 (20.25-44.0), in another one it was 26.5 (21.0-37.75) minutes. According to Mann-Whitney's U-criterion the differences between groups are statistically unreliable $(p=0.174)$. Among arterial reconstructions of kidney allograft and secondary warm ischemia time correlation is not determined $(R=0.171, p=0.176)$ (Table 1).

Artery stenosis of kidney allograft - is the most widespread vascular complication, which can be observed in the process of kidney transplantation [16]. Stenosis frequency varies within 5-23\% [1,3,12-14,17]. Probability of arterial stenosis increases in the process of transplantation of multiarterial kidney allograft. Poor surgical technique can also result in narrowing of the kidney artery: the damage of intima donor's vessels or recipient by the vascular clamps, the damage of intima donor's artery by the cannula during the process of perfusion; errors associated with the suture technique: purse-string effect of anastomosis narrowing, changing of blood flow by the stitch line, inappropriate stitching material, fiber-inflammatory reaction on the polypropylene; renal artery's inflection as a result of its insufficient or excessive length; renal artery's torsion; anastomosis «end-to-end» among the vessels, inappropriate diameter $[1,3,12-14,17]$. During ultrasonic examination of kidney allograft the following features of arterial stenosis are determined: pulse wave like "tardus-parvus", peak systolic velocity (PSV) of blood flow in the renal artery $>250 \mathrm{~cm} / \mathrm{s}$, formation between stenotic and prestenotic segments of velocity gradient $>2: 1$, decreasing the index of resistance $(\mathrm{IR})<0.56[15,18]$. Hemodynamic significant stenosis of kidney allograft artery $(>70 \%$, pressure gradient $>15 \mathrm{~mm}$ of mercury column) more likely leads to the kidney allograft's function violation and has the tendency to the progress with the continuous risk of the transplant loss $[1,12-17]$. At the same time stenosis can lead to the kidney allograft artery thrombosis [19].

PSV of blood flow in the first group was $89.1 \pm 24.6$, in average in another group was $-(96.9 \pm 33.6) \mathrm{cm} / \mathrm{s}$. Following the results of $t$-criterion for independent samples the differences among the groups are statistically unreliable $(p=0.450)$. Between the surgery on the transplant's arteries and PSV, there is no correlation $(r=-0.096, p=0.457)$.

The average index of resistance in renal artery of the transplant in the first group was $0.7 \pm 0.2$, in another group was $-0.6 \pm 0.1$. Following the t-criterion for independent samples the significant differences were not noticed $(p=0.448)$. Between the arterial reconstructions of kidney allograft and value IP correlation is not determined $(r=0.095, p=0.448)$ (Table 2).

The frequency of artery thrombosis of allograft varies within $0.2-7.5 \%$. Thrombosis develops during the first week (the most frequently during the first two-three days) after kidney transplantation $[1,3,12-16]$. The risk factor of arterial thrombosis is the use of multiarterial kidney allograft. Some errors of surgical technique can lead to the thrombosis: unidentified intimal tear, technique defects of vascular stitch, artery's inflection (if the artery is longer than vein or if there is wrong localization of anastomosis formation) [1,3,12-16,20]. The lack of arterial and vein blood flow in kidney allograft is determined in the process of Doppler study [15,18]. Taking
Table 1. Ischemia time

\begin{tabular}{lll}
\hline Ischemia time & $\begin{array}{l}\text { First group } \\
(\mathbf{n}=12)\end{array}$ & $\begin{array}{l}\text { Second group } \\
(\mathbf{n}=54)\end{array}$ \\
\hline Cold ischemia (hours) & $2.25(2.04-3.18)$ & $2.0(1.5-2.27)^{\star}$ \\
Secondary warm ischemia (minutes) & $39.0(20.25-44.0)$ & $26.5(21.0-37.75)$ \\
\hline
\end{tabular}

*: $p<0.05$ with the usage of Mann-Whitney's U-criterion.

Table 2. Average indexes of ultrasonic examination of kidney allograft arterial blood flow

\begin{tabular}{lll}
\hline $\begin{array}{l}\text { Features of ultrasonic } \\
\text { examination }\end{array}$ & $\begin{array}{l}\text { The first group } \\
(\mathbf{n}=12)\end{array}$ & $\begin{array}{l}\text { The second group } \\
(\mathbf{n}=54)\end{array}$ \\
\hline PSV $(\mathrm{cm} / \mathrm{s})$ & $89.1 \pm 24.6$ & $96.9 \pm 33.6^{*}$ \\
IR & $0.7 \pm 0.2$ & $0.6 \pm 0.1^{*}$ \\
\hline
\end{tabular}

*: the $p$-value was non-significant $(p>0.05)$.

Table 3. Duplex examination with scanning of kidney allograft

\begin{tabular}{lll}
\hline Features of ultrasonic examination & $\begin{array}{l}\text { The first group } \\
(\mathbf{n}=12)\end{array}$ & $\begin{array}{l}\text { The second group } \\
(\mathbf{n}=54)\end{array}$ \\
\hline The lack of blood flow in kidney allograft, $\mathrm{n} / \%$ & $0 / 0.0 \%$ & $0 / 0.0 \%^{*}$ \\
Pulse wave like "tardus-parvus", n/\% & $0 / 0.0 \%$ & $0 / 0.0 \%^{*}$ \\
IR $<0.56, \mathrm{n} / \%$ & $2 / 16.7 \%$ & $14 / 25.9 \%^{*}$ \\
PSV in renal artery $>250 \mathrm{~cm} / \mathrm{s}, \mathrm{n} / \%$ & $0 / 0.0 \%$ & $0 / 0.0 \%^{*}$ \\
Velocity gradient (between stenotic and prestenotic & $0 / 0.0 \%$ & $1 / 1.9 \%^{*}$ \\
segments) $>2: 1, \mathrm{n} / \%$ & & \\
\hline
\end{tabular}

*: the $p$-value was non-significant $(p>0.05)$.

into account the lack of collateral vessels and low tolerance for warm ischemia such grafts are necessary to remove in the most cases $[1,3,12-16,20]$.

In the process of Doppler study, the features of critical violation of blood flow in kidney allograft were not identified (Table 3). The differences among the groups are statistically unreliable $(p>0.05)$.

In accordance with the literature data different variants of vascular anastomosis in the process of multiarterial kidney allograft transplantation are proposed. In the process of transplantation of dead donor kidney multiple renal arteries on the common aortic Carrel's area anastomose like "toward the end" with external iliac artery of recipient. If the length of Carrel's aortic area is more than $2-2.5 \mathrm{~cm}$, it is possible to divide the vessels and anastomose the renal artery with external iliac artery separately. It is also possible to form the common arterial ostium after dissection of the excessive part of aorta between renal arteries $[2,3,12,13,15]$.

The majority of authors insist on the preservation of polar renal arteries, especially as for lower pole one because it blood supplies to the ureter $[2,3,12,13,15]$. Ligature of upper pole artery can be safe [21], especially when it has small hemodynamic value (diameter to $2 \mathrm{~mm}$ ) $[2,3,13,15]$.

In the process of transplantation of poliarterial kidney from a live donor some authors recommend to form the common Carrel's area with the help of donor gonadal vein [22]. Other authors report about good results of additional pole renal artery anastomosis with lower epigastric recipient's artery like "end-to-end" $[2,3,12,13,15]$. There is a point of view, according to which it is better to anastomose upper pole renal artery with upper epigastric artery, lower pole artery of graft with upper epigastric recipient's artery [23]. It is possible to perform the anastomosis of additional artery 
with the main stem of renal artery like "toward the end". If the polar artery is very short, it has been previously elongated with the fragment of donor gonadal vein [15].

It is very controversial point of view as for internal iliac artery of recipient use in the process of arterial anastomosis formation with kidney allograft. A lot of authors consider the anastomosis of renal artery with internal iliac artery as a spare variant, because anastomosis with external iliac artery is complicated for various reasons $[1,3,13,15]$. It has been noticed more frequent part of stenosis in the formation of renal artery anastomosis with internal iliac artery than in the anastomosis with external iliac artery [24]. Other authors simplify this point of view indicating the effectiveness of anastomosis with internal liac artery [25] and parity between anastomosis of renal artery with external iliac artery or internal iliac artery [26].

The formation of either common ostium or separate arterial anastomosis is equal for differential approach in order to choose the methods and precise technique of vascular anastomosis performing in kidney transplantation $[1,3,12,13,15]$.

Taking into account that artery of kidney allograft from live donor is short it is described the elongation of renal artery with the help of gonadal vein [27].

Adequate arterial reconstructions of kidney allograft are effective and safe method of kidney preparation for transplantation $[1,3,12,13,15]$. It permits to increase the donors' number [28]. It is particularly important in view of donor organs shortage nowadays [1].

In any case of kidney allograft arterial reconstruction there were not registered any stenosis, thrombosis or bleeding; the function of kidney allograft is preserved (on the $2.2 \pm 1.4$ years).

\section{Conclusions}

1. In the kidney transplantation with the peculiarities of vascular architectonics, elongation of ischemic time takes place, taking into account the performance of vascular reconstructions on the stage of «back table» and complexity of vascular anastomosis formation in the process of transplantation.

2. Adequate arterial reconstruction of kidney allograft is effective and safe method of kidney preparation for the transplantation.

3. The use of kidneys with architectonics peculiarities permits to increase the donors' number. It is particularly important in the context of current dissonance between the necessity and realization of transplantation.

\section{References}

[1] Kälble, T., Alcaraz, A., Budde, K., Humke, U., Karam, G., Lucan, M., et al. (2010) Guidelines on Renal Transplantation. European Association of Urology.

[2] Nykonenko, A. S., Zavgorodniy, S. N., Pollyakov, N. N., Gubka, A. V., Pastuhov, O. V., Laktionov, I. A., \& Sushko, Y. V. (2011) Angiosurgical aspects of kidney transplantation. Medecine today and tomorrow, 1-2(50-51), 174-177.

[3] Humar, A., Matas, A. J., \& Payne, W. D. (2006) Atlas of organ transplantation. Springer-Verlag London Limited.

[4] Taghizadeh Afshari, A., Mohammadi Fallah, M. R., Alizadeh, M. Makhdoomi, K., Rahimi, E., \& Vossoghian, S. (2016) Outcome of Kidney Transplantation From Living Donors With Multiple Renal ArteriesVersus Single Renal Artery. Iran J Kidney Dis, 10(2), 85-90.

[5] Soliman, S. A., Shokeir, A. A., Kamal, A. I., El-Hefnawy, A. S., Harraz, A. M.,
Kamal, M. M., et al. (2011) Long-term outcome of grafts with multiple arteries in live-donor renal allotransplantation: Analysis of 2100 consecutive patients. Arab J Urol., 9(3), 171-7. doi: 10.1016/j.aju.2011.07.006.

[6] Denecke, C., Biebl, M., Fritz, J., Brandl, A., Weiss, S., Dziodzio, T. et al. (2016) Reduction of Cold Ischemia Time and Anastomosis Time Correlates with Lower Delayed Graft Function Rates Following Transplantation of Marginal Kidneys. Ann Transplant, 21, 246-55. doi: 10.12659/AOT.896672

[7] Kamińska, D., Kościelska-Kasprzak, K., Chudoba, P., \& Klinger, M. (2016) Kidney Injury Due to Warm Ischemia During Transplantation Can Be Reduced. Am J Transplant, 16(5), 1639. doi: 10.1111/ajt.13641.

[8] Heylen, L., Pirenne, J., Samuel, U., Tieken, I., Naesens, M., Sprangers, B. \& Jochmans, I. (2016) The Impact of Anastomosis Time During Kidney Transplantation on Graft Loss: A Eurotransplant Cohort Study. Am J Transplant. doi: 10.1111/ajt.14031.

[9] Zorgdrager, M., Krikke, C., Hofker, S. H., Leuvenink, H. G., \& Pol, R. A (2016) Multiple Renal Arteries in Kidney Transplantation: A Systematic Review and Meta-Analysis. Ann Transplant., 29(21), 469-78.

[10] Ashraf, H. S., Hussain, I., Siddiqui, A. A., Ibrahim, M. N., \& Khan, M. U. (2013) The outcome of living related kidney transplantation with multiple renal arteries. Saudi J Kidney Dis Transpl., 24(3), 615-9.

[11] Bozkurt, B., Koçak, H., Dumlu, E. G., Mesci, A., Bahadir, V., Tokaç, M., et al. (2013) Favorable outcome of renal grafts with multiple arteries: a series of 198 patients. Transplant Proc., 45(3), 901-3. doi: 10.1016/j. transproceed.2013.02.096.

[12] Danovitch, G.M. (Ed.) (2010) Handbook of Kidney Transplantation. Lippincott Williams \& Wilkins Handbook Series.

[13] Pilotovich, V. S., \& Kalachic, O. V. (2009) Khronicheskaya bolezn pochek. Metody zamestitel'noj terapii pochek [Chronic kidney disease. Methods of replacement kidney therapy]. Moscow. [in Russian]

[14] Hibutiya, M. Sh., Pinchuk, A. V., Shmarina, N. V., Dmitriev, I. V., Storozhev, R. V., Kokov, L. S. et al. (2013) Sosudistyye oslozhneniya posle transplantatsii pochki [Vascular complications after kidney transplantation]. Bulletin of transplantology and artificial organs, $\mathrm{XV}(4)$, P. 31-38.

[15] Kalachik, O.V., \& Fedoruk, A.M. (2016) Transplantatsiya pochki: osnovnyye khirurgicheskiye metody, ul'trazvukovaya vizualizatsiya i minimal'no invazivnaya korrektsiya patologii a llografta pochki [Kidney transplantation: main surgical methods, ultrasonic visualization and minimal invasive correction of kidney allograft pathology]. Minsk: Paradox. [in Belarus]

[16] Szabo-Pap, M., Zadori, G., Fedor, R., Illesy, L., Toth, F., Kanyari, Z. et al. (2016) Surgical Complications Following Kidney Transplantations: A Single-Center Study in Hungary. Transplant Proc. Sep, 48(7), 2548-2551. doi: 10.1016/j.transproceed.2016.07.012.

[17] Nasserala, J. C., Oliveira, C. M., Cerqueira, J. B., Souza, S., Silva, S. L. Santos, L. C., et al. (2016) Artery Stenosis of the Renal Graft: Experience of a Center of Northeastern Brazil. Transplant Proc., 48(1), 74-80. doi: 10.1016/j.transproceed.2015.11.004

[18] Moreno, C. C., Mittal, P. K., Ghonge, N. P., Bhargava, P., \& Heller, M. T. (2016) Imaging Complications of Renal Transplantation. Radiol Clin North Am., 54(2), 235-49. doi: 10.1016/j.rcl.2015.09.007.

[19] Fallahzadeh, M. K., Yatavelli, R. K., Kumar, A., \& Singh, N. (2014)Acute transplant renal artery thrombosis due to distal renal artery stenosis: $A$ case report and review of the literature. J Nephropathol., 3(3), 105-8. doi: 10.12860/jnp.2014.20

[20] Ammi, M., Daligault, M., Sayegh, J., Abraham, P., Papon, X., Enon, B., \& Picquet, J. (2016) Evaluation of the Vascular Surgical Complications of Renal Transplantation. Ann Vasc Surg., 33, 23-30. doi: 10.1016/j. avsg.2016.03.002.

[21] Hiramitsu, T., Okada, M., Futamura, K., Yamamoto, T., Tsujita, M., Goto, N., et al. (2016) Impact of grafting using thin upper pole artery ligation on living-donor adult kidney transplantation: The STROBE study. Medicine (Baltimore), 95(42), e5188. doi: 10.1097/MD.0000000000005188.

[22] He, B., Mou, L., Mitchell, A., \& Delriviere, L. (2013) Meticulous use of techniques for reconstruction of multiple renal arteries in live donor kidney transplantation. Transplant Proc., 45(4), 1396-8. doi: 10.1016/j. transproceed.2012.12.013

[23] Amirzargar, M. A., Babolhavaeji, H., Hosseini, S.A., Bahar, H., Gholyaf, M., Dadras, F., et al. (2013) The new technique of using the epigastric arteries in renal transplantation with multiple renal arteries. Saudi $J$ Kidney Dis Transpl., 24(2), 247-53.

[24] Benoît, G. (2011) Surgical view of a series of 3,000 kidney transplantations. Bull Acad Natl Med., 195(2), 351-62.

[25] Tomić, A., Milović, N., Marjanović, I., Bjelanović, Z., Leković, I., Micković, S. \& Stamenković, D. (2015) Different techniques of vessel reconstruction during kidney transplantation. Vojnosanit Pregl., 72(7), 614-8. doi: 10.2298/VSP131210038T.

[26] Hwang, J. K., Kim, S. D., Park, S. C., Choi, B. S., Kim, J. I., Yang, C. W., et al. (2010) The long-term outcomes of transplantation of kidneys with multiple renal arteries. Transplant Proc., 42(10), 4053-7. doi: 10.1016/j. transproceed.2010.09.075 
[27] Uysal, E., Yuzbasioglu, M. F., Ikidag, M. A., Dokur, M., \& Gurer, O. A (2016) Successful Elongation of a Short Graft Renal Artery by a Gonadal Vein. Exp Clin Transplant., 20. doi: 10.6002/ect.2015.0002.

[28] McLoughlin, L. C., Davis, N. F., Dowling, C. M., Power, R. E., Mohan, P., Hickey, D. P., et al. (2014) Ex vivo reconstruction of the donor renal artery in renal transplantation: a case-control study. Transpl Int., 27(5), 458-66.

\section{Information about authors:}

Vildanov S. R., MD, Postgraduate Student, Department of Transplantology and Endocrine Surgery with the Course of Cardiovascular Surgery, State establishement: "Zaporizhzhia Medical Academy of Post-Graduate Education Ministry of Health of Ukraine".

Nykonenko A. O., MD, PhD, DSci, Professor, Department of Hospital Surgery, Zaporizhzhia State Medical University, Ukraine.

Rusanov I. V., MD, PhD, Associate Professor, Department of Transplantology and Endocrine Surgery with the Course of Cardiovascular Surgery, State establishement: "Zaporizhzhia Medical Academy of Post-Graduate Education Ministry of Health of Ukraine".

Nykonenko O. S., MD, PhD, DSci, Professor, Academician of the Academy of Medical Sciences of Ukraine, Corresponding Member of the Academy of Sciences of Ukraine, Rector of the State establishement: "Zaporizhzhia Medical Academy of Post-Graduate Education Ministry of Health of Ukraine", Head of the Department of Hospital Surgery, Zaporizhzhia State Medical University, Ukraine.

\section{Відомості про авторів:}

Вільданов С. Р., очний аспірант каф. трансплантології та ендокринної хірургії з курсом серцево-судинної хірургії, АЗ «Запорізька медична академія післядипломної освіти Міністерства охорони зАоров'я України".

Никоненко А. О., А-р меА. наук, професор каф. госпітальної хірургії, Запорізький державний медичний університет, Україна. Русанов І. В., канА. меА. наук, Аоцент каф. трансплантологій та ендокринної хірургії з курсом серцево-судинної хірургії, АЗ «Запорізька медична академія післядипломної освіти Міністерства охорони зАоров'я України".

Никоненко О. С., А-р меА. наук, професор, академік НАМН України, чл.-кор. НАН України, ректор АЗ «Запорізька меАична академія післядипломної освіти Міністерства охорони зАоров'я України", зав. каф. госпітальної хірургії, Запорізький державний медичний університет, Україна.

\section{Сведения об авторах:}

Вильданов С. Р., очный аспирант каф. трансплантологии и энАокринной хирургии с курсом сердечно-сосудистой хирургии, ГУ “Запорожская медицинская академия послеАипломного образования Министерства зАравоохранения Украины".

Никоненко А. А., А-р меА. наук, профессор каф. госпитальной хирургии, Запорожский государственный медицинский университет, Украина.

Русанов И. В., канА. меА. наук, Аоцент каф. трансплантологии и эндокринной хирургии с курсом сердечно-сосудистой хирургии, ГУ “Запорожская медицинская академия последипломного образования Министерства зАравоохранения Украины".

Никоненко А. С., А-р меА. наук, профессор, академик НАМН Украины, ч^.-кор. НАН Украины, ректор ГЗ «Запорожская медицинская академия последипломного образования Министерства заравоохранения Украины", зав. каф. госпитальной хирургии, Запорожский государственный меАицинский университет, Украина.

Конфмікт інтересів: віАсутній

Conflicts of Interest: authors have no conflict of interests. 